\title{
Przemoc WŚród osób STARszych a SUMienie JeJ SPRAW- CÓW - ASPEKT ETYCZNY I SPOŁECZNO-PRAWNY
}

\section{Wstęp}

Jeszcze do niedawna kwestia zaniedbań i nadużyć wobec osób starszych nie była poruszana. Koncentrowano się przede wszystkim na zjawisku przemocy w stosunku do dzieci bądź kobiet młodych. Prowadzone w Polsce badania pokazuja, iż akty przemocy wobec seniorów w środowisku rodzinnym dokonywane są przede wszystkim przez współmałżonków ofiar (58\%) oraz dzieci (24\%), przy czym znacznie częściej synów niż córki ${ }^{1}$.

W niniejszej pracy zaprezentowany zostanie aspekt przemocy z punktu widzenia sprawcy przemocy. Problematyka nie będzie dotyczyć każdego sprawcy sytuacji przemocowej, a jedynie osób w starszym wieku, tj. 60 i więcej lat, bowiem zgodnie $\mathrm{z}$ literatura gerontologiczną za próg starości uznaje się w przypadku obu płci 60. lub 65. rok życia².

Podstawę analiz stanowią badania empiryczne przeprowadzone przez autorkę artykułu w trzech domach pomocy społecznej województwa podlaskiego w latach 2011 i 2012. W celu pogłębienia problemu i wzbogacenia

* Dr, Państwowa Wyższa Szkoła Informatyki i Przedsiębiorczości w Łomży; e-mail: annaszafranek01@gmail.com

${ }^{1}$ M. Halicka, J. Halicki (red.), Przemoc wobec ludzi starych, Białystok 2010, a także M. Cichocka, Zjawisko i formy przemocy wobec ludzi starych, [w:] Agresja i przemoc a zdrowie psychiczne, Warszawa-Poznań 2001, s. 213-218.

2 B. Szatur-Jaworska, P. Błędowski, M. Dzięgielewska, Podstawy gerontologii społecznej, Warszawa 2006, s. 46. 
wiedzy na temat osób w starszym wieku stosujących przemoc i osób doznających przemocy uwzględnione zostaną także informacje pochodzące $\mathrm{z}$ realizacji dwóch europejskich projektów badawczych poświęconych zjawisku przemocy intymnej $\mathrm{w}$ związkach małżeńskich/partnerskich wobec kobiet $\mathrm{w}$ starszym wieku (informacje $\mathrm{z}$ badań oraz dokumentacji sądowej) ${ }^{3}$.

Literatura dotycząca przemocy wobec ludzi starych zwykle koncentruje uwagę na seniorze jako ofierze takiego działania, rzadko natomiast jest mowa o osobie starszej występującej w roli agresora, co sprzyja powstawaniu sytuacji przemocy. Wydaje się, że w takiej sytuacji istotne są także uczucia towarzyszące sprawcy w czasie popełniania niedozwolonego czynu. Interesujące wydają się być pytania: czym kieruje się człowiek w starszym wieku, wyrządzając krzywdę innej osobie? Czy zastanawia się nad swoim postępowaniem? Czy zdaje sobie sprawę z konsekwencji swojego zachowania? Czy ma wyrzuty sumienia?

J. Maritain zwracał uwagę, że powinniśmy czynić wszystko, co jest po ludzku możliwe i co nam podpowiada sumienie ${ }^{4}$. Jednak rodzi się pytanie: dlaczego niektóre osoby krzywdzą innych? Co podpowiada sprawcom przemocy ich sumienie?

Punktem wyjścia niniejszych rozważań są filozoficzne teorie podejmujące problematykę sumienia, poglądy wybitnego socjologa prawa - Leona Petrażyckiego, jak również wyniki badań dotyczące przemocy wobec osób starszych i z udziałem osób starszych.

\section{Pojęcie i formy przemocy - analiza społeczno-prawna}

Na podstawie badań międzynarodowych ${ }^{5}$ podejmujących problematykę przemocy względem starszych kobiet ze strony męża można stwierdzić, iż mężczyźni, którzy stosowali przemoc względem swoich żon

${ }^{3}$ DAPHNE III Intimate Partner Violence against Older Women (2009-2010); DAPHNE III Mind the Gap! Improving Intervention in Intimate Partner Violence against Older Women (20122013); szczegółowe informacje dotyczące projektów i raporty: www.ipvow.org [dostęp: 24.01.2017 r.]

${ }^{4}$ J. Maritain, Pisma filozoficzne, tłum. J. Fenrychowska, Kraków 1988, s. 216.

5 DAPHNE III Intimate Partner Violence against Older Women (2009-2010); DAPHNE III "Mind the Gap! Improving Intervention in Intimate Partner Violence against Older Women (2012-2013). 
w większości przypadków nie cierpieli na żadne zaburzenia bądź choroby psychiczne. Nie oznacza to, że nie mieli deficytów psychologicznych bądź społecznych. Ale czy owymi deficytami należałoby obarczać wszystkich winnych niewłaściwego postępowania? Co z sumieniem sprawcy przemocy, które powinno odpowiadać za umiejętność rozróżniania dobra od zła i pomagać człowiekowi w podejmowaniu właściwych decyzji? Czy dzieje się tak dlatego, że sprawca nie ma sumienia, czy też może dlatego, iż przemoc jest zjawiskiem płynnym oraz trudnym do zdefiniowania? Każdy człowiek może definiować ją w inny sposób, co oznacza, że konkretne zachowanie jednej osoby może być traktowane jako forma przemocy, podczas gdy inna osoba będzie to postrzegała inaczej.

Należy mieć na uwadze, że do 2005 r. w polskim systemie prawnym nie funkcjonowało pojęcie przemocy. W związku z tym instytucje badające tę kwestię posługiwały się definicjami akademickimi bądź posiłkowały się rozwiązaniami zaczerpniętymi z Kodeksu karnego ${ }^{6}$. Dopiero ustawa o przeciwdziałaniu przemocy z dnia 29 lipca 2005 r. zdefiniowała przemoc jako jednorazowe bądź powtarzające się umyślnie działanie lub zaniechanie naruszające prawa lub dobra osobiste osób najbliższych, a także osób wspólnie zamieszkujących. W szczególności chodzi tu o narażenie osób na niebezpieczeństwo utraty życia, zdrowia, naruszające godność, nietykalność cielesna, wolność, powodowanie szkód na zdrowiu psychicznym bądź fizycznym, a także wywoływanie krzywd i cierpień moralnych ${ }^{7}$.

Znowelizowana ustawa o przeciwdziałaniu przemocy $\mathrm{z}$ dnia 10 czerwca 2010 r. uznaje, iż przemoc narusza podstawowe prawa człowieka, w tym prawo do życia, zdrowia, jak również poszanowania godności osobistej ${ }^{8}$.

Przywołane ustawy formalizują rozumienie terminu "przemoc", który zwykle kojarzy się z następującymi określeniami: bicie, maltretowanie,

${ }^{6}$ Ustawa z dnia 6 czerwca 1997 r. - Kodeks karny, Dz. U. z 2016 r. poz. 1137 z późn. zm. M. Halicka, J. Halicki, Przemoc wobec ludzi starych jako przedmiot badań, [w:] M. Halicka, J. Halicki (red.), Przemoc wobec ludzi starych, Białystok 2010, s. 20. Chodzi o: przestępstwa przeciwko życiu i zdrowiu: art. 148, 156, 157, 158, 159 k.k., przestępstwa przeciwko wolności: art. 189, 190, 191 k.k., przestępstwa przeciwko wolności seksualnej i obyczajowości: art. 197, 198, 199, 200 k.k., przestępstwa przeciwko rodzinie i opiece: art. 207 k.k., przestępstwa przeciwko czci i nietykalności cielesnej: art. 216, 217 k.k.

7 Ustawa z dnia 29 lipca 2005 r. o przeciwdziałaniu przemocy w rodzinie, Dz. U. z 2015 r. poz. 1390 .

${ }^{8}$ Ustawa z dnia 10 czerwca 2010 r. o zmianie ustawy o przeciwdziałaniu przemocy w rodzinie oraz niektórych innych ustaw, Dz. U. Nr 125, poz. 842. 
nadużycie, krzywdzenie, okrucieństwo, opresyjność, znęcanie się, zmuszanie. W literaturze gerontologicznej przemoc traktowana jest $\mathrm{w}$ kategoriach nadużyć i zaniedbań, rzadziej maltretowania9. Ponadto osoby starsze doświadczają najczęściej następujących form przemocy:

- przemoc fizyczna (uderzanie, policzkowanie, popychanie, rzucanie w kogoś przedmiotami);

- przemoc psychiczna (obwinianie, zastraszanie, przeklinanie, agresja słowna, traktowanie osoby starszej jak dziecka);

- przemoc finansowa (kradzież, odmawianie osobom starszym dostępu do własnych funduszy);

- przemoc seksualna (sugestywne rozmowy, dotykanie, gwałt, obnażanie się, fotografowanie);

- przemoc symboliczna (dyskredytacja własnego dorobku kulturowego, wymuszanie noszenia odpowiedniego stroju, bądź mówienia danym językiem);

- zaniedbania (zaniechanie dostarczania jedzenia, schronienia, odzieży, opieki medycznej, kontaktów społecznych);

- opuszczenie $^{10}$.

Niezależnie od tego, czy przemoc postrzegana jest z punktu widzenia jednostkowego czy społecznego, zawsze kojarzy się z czymś złym, niesprawiedliwym, okrutnym, bolesnym. Dlaczego zatem sprawca przemocy nie zdaje sobie sprawy, jak bardzo swoim zachowaniem krzywdzi ofiarę? A być może sprawca zdaje sobie sprawę ze swojego postępowania, ale nie chce nic z tym zrobić? Czy to oznacza, że sprawca przemocy może być pozbawiony sumienia? A jeśli nie jest pozbawiony, to dlaczego owo sumienie jest sumieniem milczącym? Czy nastąpiły jakieś błędy, wypaczenia, wskutek czego sumienie człowieka, który dopuszcza się stosowania przemocy funkcjonuje w sposób wadliwy? Trudno udzielić odpowiedzi w sposób jednoznaczny na tak postawione pytania. Pomocne będzie - jak się wydaje - poznanie sumienia sprawcy oraz mechanizmu jego funkcjonowania.

${ }^{9}$ M. Kosiorek, Przemoc symboliczna w edukacji, [w:] R. Szczepanik, J. Wawrzyniak (red.), Różne spojrzenia na przemoc, Łódź 2008, s. 47.

${ }_{10}$ M. Halicka, A. Szafranek, Zjawisko przemocy w populacji osób starszych, [w:] M. Cybulski, E. Krajewska-Kułak (red.), Opieka nad osobami starszymi. Przewodnik dla zespołu terapeutycznego, Warszawa 2016, s. 189. 


\section{Sumienie i mechanizm jego funkcjonowania}

W słowniku terminów filozoficznych sumienie określane jest jako „zdolność wydawania sądów dotyczących wartości moralnej czynów ludzkich, a zwłaszcza własnego postępowania podmiotu"11. Zdaniem autorów, w zależności od tego, jaka teoria zostanie zastosowana, można traktować sumienie jako pierwotną zdolność człowieka bądź nadawać mu charakter pochodny. Rozum z kolei po poznaniu zarówno zewnętrznych, jak i wewnętrznych okoliczności działania dokonuje moralnej oceny czynów, zobowiązuje również podmiot do podejmowania bądź zaprzestania pewnych działań w przyszłości. Istnieje możliwość, że sumienie ulega wypaczeniu. Dzieje się tak wówczas, gdy rozum źle odczytuje normy moralne i kieruje się $\mathrm{w}$ sądach sumienia ich błędnym rozumieniem ${ }^{12}$.

Św. Bonawentura czy też Jan Duns Szkot wiązali funkcjonowanie sumienia bardziej z ludzką wolą niż rozumem. Wola w sposób naturalny powinna skłaniać człowieka do czynów moralnie dobrych, a odwracać od złych. Należy jednak zauważyć, iż aby owa skłonność woli, nie była tylko i wyłącznie ślepą siła, powinna być poprzedzona poznaniem dobra ${ }^{13}$.

Ciekawą koncepcję sumienia przedstawiał również św. Tomasz z Akwinu, gdyż prezentował on sumienie uwikłane $w$ dualizm dobra i zła. Sumienie pozwala ludziom złym wznosić się ku dobru, gdyż prawo moralne Bóg wpisał nie tylko w sercach ludzi dobrych, ale również tych skłonnych do czynienia zła. Podkreśla również, że w swoich zasadach powinniśmy kierować się dobrem i do niego zmierzać. Sumienie nie pełni roli władzy w człowieku, a rolę naturalnej jego sprawności ${ }^{14}$.

Psychologiczne ujęcie sumienia różni się nieco od sygnalizowanych wyżej podejść. Współczesne psychologiczne podejście nie utożsamia sumienia z głosem Boga, a tym samym nie uznaje go za wrodzone. Zakłada, że zarówno zakazy, jak również nakazy sumienia są nabyte ${ }^{15}$. Wydaje się jednak, iż sumienie nie jest zdolnością nabytą, a wrodzoną.

11 Sumienie, [w:] A. Podsiad, Z. Więckowski (opr.), Mały słownik terminów i pojęć filozoficznych dla studiujących filozofię chrześcijańska, Warszawa 1983, s. 374.

12 Tamże, s. 375.

13 T. Biesaga, Sumienie, [w:] Powszechna encyklopedia filozoficzna, t. 9, Lublin 2008, s. 267270.

14 Św. Tomasz z Akwinu, Traktat o człowieku. Summa teologii, 1, 75-89, tłum. i oprac. S. Swieżawski, Kęty 2000, s. 337.

15 A.S. Reber, E.S. Reber, Stownik psychologii, Warszawa 2008, s. 756. 
Również L. Petrażycki nawiązuje w swoich pismach do tematyki sumienia, pisząc, iż w umyśle ludzkim pojawiają się emocje, które zarówno popychają jak i przeciwdziałają podejmowaniu konkretnych działań. W efekcie dochodzi do wewnętrznego tarcia między różnymi emocjami, prowadzącego do wewnętrznego głosu sumienia, które pewne postępowanie popiera, inne odrzuca ${ }^{16}$. Autor widzi sumienie jako swego rodzaju bufor, którego zadanie polega na wyborze właściwego postępowania.

Biorąc pod uwagę, iż Bóg stworzył człowieka na swój obraz i podobieństwo - to zaopatrzył każdego w sumienie, które winno być głosem wyrywającym z marazmu, ciemności, zła i lęku. Sumienie powinno czuwać nad postępowaniem człowieka, kierować nim, by stawał się na obraz i podobieństwo Boga. W tym kontekście słowa św. Tomasza wydają się być znamienne. Oznacza to, iż błędem jest stwierdzenie, że sprawca przemocy nie ma sumienia. Każdy człowiek, istota rozumna posiada sumienie. Bez niego zło dominowałoby nad dobrem, a tak nie jest. Jeżeli jednak człowiek ma sumienie, to rodzi się pytanie: dlaczego istnieje zło? Dlaczego stosowana jest przemoc? Czy to rozum podpowiada sumieniu złe wybory? W tym miejscu istotne jest odwołanie do pism Petrażyckiego dotyczących praw kobiet, które są skierowane „do wszystkich ludzi o sumieniu rozwiniętym i kulturalnym", gdyż osoby posiadające deficyty nie potrzebują sięgania do pism, a przede wszystkim wychowania ${ }^{17}$. A zatem nie wystarczy mieć sumienie, kluczowe w tym przypadku wydaje się dbanie o jego ustawiczny rozwój.

\section{Uwarunkowania przemocy}

Przytoczone wyżej ujęcia sposobów działania sumienia w pewnym stopniu tłumaczą mechanizm działania sumienia sprawcy przemocy. Najbardziej pomocne $w$ analizie sumienia sprawcy przemocy są - jak można sądzić - ujęcia św. Bonawentury i Jana Dunsa Szkota, choć św. Tomasz również podkreśla kluczową rolę dobra w działaniu sumienia. Oznacza to, że wola, rozum i sumienie są ze sobą nierozerwalnie związane. A zatem podstawę sytuacji przemocowej może stanowić fakt, iż sprawca nie

\footnotetext{
${ }^{16}$ L. Petrażycki, Emocjonalne zarażenia, „Studia Socjologiczne” 2011, nr 2 (201), s. 21.

17 Tenże, O nauce, prawie i moralności. Pisma wybrane, Warszawa 1985, s. 379.
} 
poznał wcześniej dobra. $\mathrm{W}$ trakcie prowadzonych $\mathrm{w}$ domach pomocy społecznej wywiadów ze sprawcami przemocy ${ }^{18}$ wielokrotnie słyszano, iż badany nie ma dobrych kontaktów z rodziną, część sprawców jest po rozwodzie, część z nich nie zajmowała się swoimi bliskimi. W diagnozie uwarunkowań takich działań uwzględniono fakt, iż sprawcy przenoszą własne doświadczenia z dzieciństwa do zakładanych przez siebie rodzin. Osoby stosujące przemoc często przyznawały, iż nie mają kontaktu ze swoim ojcem, ponieważ ojciec nie interesował się życiem rodzinnym, spożywał alkohol bądź stosował wobec nich przemoc. Można więc sądzić, iż nie wpoił dzieciom zasad moralnych, nie nauczył również czynienia dobra. Z przeprowadzonych badań wynika, że respondenci zarówno $\mathrm{w}$ przeszłości, jak i obecnie nie widzieli potrzeby utrzymywania kontaktów z własnym ojcem ${ }^{19}$. Zwraca uwagę fakt, iż takie negatywne postawy są powielane przez sprawców i dotyczą ich rodzin (w szczególności żon i dzieci), które w wielu wypadkach muszą samodzielnie sprostać trudnej sytuacji życiowej ${ }^{20}$.

Zwykle przemoc nie rodzi się nagle, a narasta przez wiele lat; bardzo rzadko osoba, która przez całe życie nie stosowała przemocy dopiero w podeszłym wieku zaczyna się nad kimś znęcać. Takie zachowania mogą trwać przez wiele lat. Dorastanie w atmosferze przemocy domowej zwiększa prawdopodobieństwo przejawiania podobnych zachowań w swoim dorosłym życiu. Ponadto przemoc jest zjawiskiem dotyczącym zarówno seniorów zamieszkujących środowisko instytucjonalne, jak również pozostających $\mathrm{w}$ domu rodzinnym. Środowisko instytucjonalne, np.

${ }^{18}$ Badania zrealizowane na przełomie 2011 i 2012 r., w trzech domach pomocy społecznej województwa podlaskiego - w sumie zrealizowano 60 wywiadów z osobami starszymi - mieszkańcami placówek (po 20 w każdym dps) i 30 wywiadów z pracownikami instytucji (po $10 \mathrm{w}$ każdym dps). W badaniach wzięły udział 24 podopieczne i 36 podopiecznych placówek, bowiem mężczyźni chętniej wyrażali zgodę na udział w badaniach. Próbę dobrano w sposób celowy, według następujących kryteriów: wywiady prowadzono z osobami w wieku min. 60 lat, bez zaburzeń psychicznych, mieszkających w placówce minimum rok. Ponadto personel instytucji wskazywał osoby agresywne, stosujące przemoc bądź popadające w konflikty częściej niż inni, jak również osoby szczególnie podatne na bycie ofiarą.

19 „Matka nie żyje, a ojciec to nie wiem, może żyje, może nie (...) Jak on mną nie opiekował się, to czemu ja mam się nim interesować?" - mężczyzna, 63 lata.

20 „Dzieci mam dwoje (...) nie mam z nimi kontaktu (...) jak one mnie nie znają, widziałem jak dzieci małe, w dobrych ręcach są" - mężczyzna, 63 lata; „Z żoną rozeszliśmy się z 10 lat temu, z córką kontaktu nie mam, ona prawdopodobnie do Anglii wyjechała. Tego dokładnie nie wiem”. - mężczyzna 60 lat; „Mam wprawdzie syna, ale nie utrzymuję z nim kontaktów, raczej on ze mną". - kobieta, 67 lat. 
przez konieczność dostosowania się do obowiązujących zasad, konieczność dzielenia pokoju z inną osoba, negatywne relacje czy atmosferę panującą $\mathrm{w}$ instytucji może wprawdzie potęgować stosowanie przemocy ${ }^{21}$, co jednocześnie nie oznacza, że stosowanie przemocy stanowi specyfikę tylko i wyłącznie w przypadku osób zamieszkujących domy pomocy społecznej.

Analiza danych uzyskanych w ramach projektu Mind the Gap! wskazuje, iż 92,9\% mężczyzn w podeszłym wieku - sprawców przemocy, wykazywało zachowania przemocowe już od pierwszych lat trwania małżeństwa, zaś 28,6\% miało wcześniejsze wyroki sądowe za stosowanie przemocy ${ }^{22}$. Tym samym to nie podeszły wiek miał kluczowe znaczenie w podejmowaniu działań przemocowych, a „właściwości, czyli cechy osobowościowe sprawcy i cechy nabyte w procesie socjalizacji” oraz „działania podjęte przez partnera, np. nadużywanie alkoholu, zdrada małżeńska, fobie i zaburzenia w kontaktach seksualnych, jak również chęć zawłaszczenia majątku" ${ }^{\prime 23}$. Istotnym jest, iż zdarzały się sytuacje, w których częstotliwość stosowania przemocy dramatycznie nasiliła się wraz z wiekiem partnera (przejście na emeryturę jako czynnik powodujący przemoc) ${ }^{24}$.

\section{Sumienie sprawcy przemocy}

Św. Jan Paweł II w Encyklice Veritatis splendor wskazywał, iż we współczesnej kulturze zanika relacja prawda - dobro - wolność ${ }^{25}$. Papież zastanawiał się wówczas jaką koncepcję sumienia powinien wybrać współcześnie żyjący człowiek, by żyć zgodnie z nauką kościoła. Ojciec Święty zastanawiał się, czy ludzkości nie grozi zaćmienie sumienia. Te pytania

${ }^{21}$ A. Szafranek, Czynniki sprzyjające przemocy z udziałem osób starszych w domach pomocy społecznej w województwie podlaskim, [w:] P. Błędowski, A. Stogowski, K. Wieczorowska-Tobis (red.), Wyzwania wspótczesnej gerontologii, Poznań 2013, s. 83-96.

${ }^{22}$ M. Halicka, A. Szafranek, The living space of elderly female victims of intimate partner violence in view of court acts, [w:] J. Maćkowiak, E. Pająk-Ważna (red.), Women in different global contexts, Kraków 2014, s. 248.

${ }^{23}$ M. Halicka, Przemoc wobec starszych kobiet - wywiady z ofiarami „Praca Socjalna” 2012, nr 5, s. 154-155.

${ }^{24}$ Tamże, s. 158-160.

${ }^{25}$ http://www.nonpossumus.pl/encykliki/Jan_Pawel_II/veritatis_splendor/III.php [dostęp: 19.11.2012 r.] 
zadawane były w kontekście ogółu społeczeństwa, ale równocześnie można je odnieść do sprawców przemocy. Jeśli w ich życiu nie dane im było doświadczyć dobra (zwykle ze strony rodziców, a konkretnie ze strony ojca), to sami również od niego stronią.

We współczesnym świecie obserwujemy zanik fundamentalnych wartości w relacjach międzyludzkich. Chodzi tu o prawdę - dobro - wolność, które to wartości w coraz mniejszym stopniu wpływają i kształtują sumienie współczesnego człowieka. J. Mariański zauważa, iż w obecnym świecie odchodzi się od postrzegania tego co słuszne (wartości), na rzecz tego co korzystne (interesy) ${ }^{26}$. Przy czym ludzkie zachowania i postępowanie $\mathrm{w}$ dużym stopniu jest kierowane emocjami ${ }^{27}$, zaś jednym $\mathrm{z}$ najważniejszych interesów w przypadku badanych respondentów domów pomocy społecznej jest przede wszystkim zdobycie funduszy na zakup alkoholu, nawet kosztem innych osób - czyli uciekanie się do stosowania przemocy ekonomicznej. W takich przypadkach wyraźnie widać, w jaki sposób negatywne emocje mogą doprowadzić do zachowań przemocowych.

Nie oznacza to, że sprawcy przemocy nie słyszą wewnętrznego głosu, wołania swojego sumienia, by na chwilę zatrzymali się, zastanowili się nad swoim postępowaniem, a być może nawet opamiętali, należy jednak zwrócić uwagę, iż w większości przypadków ów głos jest zagłuszany (najczęściej przez alkohol). Ale nawet gdyby sprawca nie spożywał alkoholu - jak mógłby wrócić do właściwego postępowania, jeżeli w wielu wypadkach nie wie, czym owo właściwe postępowanie jest? Badania zrealizowane w domach pomocy społecznej województwa podlaskiego wskazały, że duża część sprawców przemocy nie wyniosła wzorców dobrego postępowania z domu, gdyż przewodnikami życia w tym przypadku nie byli rodzice. Zwykle tę funkcję pełniła grupa rówieśnicza, grupa sąsiedzka, bądź grupa przestępcza ${ }^{28}$.

Wyobrażenie sobie starości często podsuwa obrazy szczęśliwych dziadków, którzy mogą cieszyć się z wnuków oraz zasłużonej emerytury.

${ }^{26}$ J. Mariański, Kryzys moralny czy transformacja wartości? Studium socjologiczne, Lublin 2001, s. 13.

${ }^{27}$ K. Motyka, Wpływ Leona Petrażyckiego na polska teorię i socjologię prawa, Lublin 1993, s. 93.

28 „Lubię wędkować, ale teraz nie wędkuję, bo kolega u którego wędki trzymam to zaszlachtował drugiego, bo z bandyckiej dzielnicy pochodzę". - mężczyzna, 63 lata; „Koledzy mnie wychowywali i od małego piłem 2 razy dziennie, jak kolegów miałem, jak pieniądze miałem to kolegów miałem, jak pieniędzy nie było to i kolegów nie było". mężczyzna, 60 lat. 
Czasem jest to także pesymistyczna myśl związana z chorobami towarzyszącymi wiekowi starczemu. Jednak większości osób nie towarzyszy obraz seniora, który będąc pod wpływem alkoholu ubliża innym. Niestety, alkoholizm w przypadku badanych podopiecznych domów pomocy społecznej (kwestia dotyczy nie tylko mężczyzn) jest palącym problemem, z jakim borykają się pracownicy tych placówek ${ }^{29}$. Wydaje się, że jest to w pewnym stopniu ucieczka od problemów, a być może pojawiających się wyrzutów sumienia.

Trudno wczuć się w rolę sprawców przemocy. Z uzyskanych wypowiedzi mieszkańców instytucji opiekuńczych wynika, że żaden z nich nie żałuje swoich czynów, żaden z nich nie przeprosił również osób, którym ową krzywdę wyrządził. Jednak czy to oznacza, że nie zdają sobie sprawy z tego co czynią? Wydaje się, że człowiek nie jest w stanie zagłuszyć swojego sumienia. Nawet jeśli uparcie do tego dąży, to jednak w pewnym momencie nastąpi przełom, może będzie to sytuacja kryzysowa, która udzieli głosu sumieniu sprawcy. W przypadku badanych podopiecznych domów pomocy społecznej zwykle takim momentem przełomowym, w którym przyszło wytchnienie i chwila refleksji nad swoim dotychczasowym życiem była zapaść alkoholowa. W przypadku alkoholika seniora, sprawcy przemocy, taki przełomowy moment nadchodzi zwykle dopiero wtedy, kiedy ociera się o śmierć. Wówczas przychodzi refleksja, skupienie, wsłuchanie się w głos własnego sumienia, co w niektórych przypadkach skutkuje chęcią poprawy swojego zachowania. To właśnie takie momenty życiowe pokazują że każdy człowiek, nawet ten postępujący niewłaściwie, ma sumienie, które dochodzi do głosu.

Z wypowiedzi mieszkańców instytucji opiekuńczych wynika, że ci, którzy stosują przemoc próbują usprawiedliwiać swoje zachowanie trudnym dzieciństwem, w wielu przypadkach również nieudanym życiem czy też błędnie podjętymi decyzjami. Seniorzy biorący udział w badaniach prowadzonych w domach pomocy społecznej nie mieli żadnych planów na przyszłość, nie widzieli sensu swojego życia, nie chcieli już o niczym

${ }^{29}$ „Ten co ze mną mieszka, ten drugi, on niedobry. A ten siedział w ciupie i przyszedł i znów. On mnie zniszczy z tego świata. I nie przyzna ani Bogu, ani mnie. On taki niedolatek, a pieniądzy dostaje, opiekuńcze dostaje a on pije i mnie pieniądzy zabiera". - mężczyzna, 99 lat; „Chociaż ona to jest ciężka koleżanka do współżycia takiego. Ona jest cholernie agresywna, coś nie tak to od razu łomot z jej strony. Któregoś razu był taki łomot, że aż przykro mówić, wie pani, ale to jest prawda, że na izbie wytrzeźwień obie się znalazłyśmy. Na jednej sali nas nie położyli. Ja na jednej, ona na drugiej" - kobieta, 66 lat. 
marzyć. Zwykle czekali na śmierć, która, jak sami mówią: nie chce do nich przyjśćc $^{30}$. Z pewnością nie jest to wizja szczęśliwej starości.

\section{Kara jako sposób przeciwdziałania przemocy}

Warto zastanowić się, czy deficyty w doświadczaniu dobra da się w jakiś sposób nadrobić. W jaki sposób postępować, pracować z osobami stosującymi przemoc, z osobami w podeszłym wieku, podopiecznymi placówek opiekuńczych, by zaprzestali działań przemocowych? Jak spowodować, by w swoim zachowaniu kierowali się sumieniem i tym co ono podpowiada? Czy seniorów stosujących przemoc należy karać? Czy to właściwa droga? Odpowiedź na tak postawione pytania nie jest łatwa.

Niewątpliwie kara kojarzona jest z działaniem, które w oczach innych zasługuje na potępienie przez zastosowanie takiej sankcji, która w ramach działań prewencyjnych powstrzyma w przyszłości jednostkę od ponownego popełnienia przestępstwa ${ }^{31}$. Dlatego też zastosowanie kary jest słuszne. Jednak rodzi się pytanie: jaki rodzaj kary wybrać? Filozoficznym problemem samej kary jest odpowiedź na pytanie: czy karze się za to, że popełniono przestępstwo czy też po to, aby zapobiec popełnieniu kolejnego przestępstwa? Aby dać odpowiedź na tak postawioną kwestię, warto odnieść się do sposobu uzasadniania stosowania kary: stosowanie bezwzględne (odwetowe, absolutne, metafizyczne, retrybutywne), względne (celowościowe, prewencyjne, utylitarne) oraz mieszane (koalicyjne), które łączą oba poprzednie punkty widzenia, odrzucając jednocześnie stanowiska ekstremalne ${ }^{32}$. Aby lepiej zobrazować sytuacje przemocy i podejmowane działania wymiaru sprawiedliwości i organów ścigania odnośnie do stosowania kar, niżej zaprezentowano wyniki badań realizowanych w ramach międzynarodowego projektu Mind the Gap! ${ }^{33}$ Na podstawie analizy

30 "Jakiż to sens, nie ma żadnego sensu to życie”. - mężczyzna, 80 lat; „A jaki tu sens życia, jak nie ma tu żadnego sensu życia. Tylko, że żyję, bo muszę. (...) Bo ja kiedyś chciałem się utopić. (...) Miałby spokój, bo jak wody napije się, znaczy w stawie to wtedy szybka śmierć, znaczy bezbolesna". - mężczyzna, 75 lat.

${ }^{31}$ H. Leszczyna, Petrażycki, Warszawa 1974, s. 127.

32 J. Świtka, Filozoficzne i socjologiczne ujęcie kary, [w:] M. Kuć, I. Niewiadomska (red.), Kara kryminalna. Analiza psychologiczno-prawna, Lublin 2004, s. 16-17.

33 Szczegółowa treść raportu z projektu: http://www.ipvow.org/images/ipvow/manuals/Poland_case_file_analysis_Polish_version.pdf [dostęp: 24.01 .2017 r.] 
70 akt sądowych dotyczących przestępstwa z art. 207 k.k., w przypadku stosowania przemocy względem współmałżonka w wieku 60 i więcej lat, sąd zwykle wymierzał karę pozbawienia wolności w zawieszeniu, dozór kuratora, a także środek karny w postaci powstrzymania się od spożywania alkoholu. Okazuje się jednak, iż taki rodzaj kary nie spełnia oczekiwań. Ze sporządzonych informacji kuratorskich wynika, że sprawcy zwykle nie powstrzymywali się od nadużywania alkoholu, nie zaprzestawali również stosowania przemocy wobec swoich współmałżonek. Kara to nic innego jak pewien przymus, a ten dla osób starszych nie jest łatwy do spełnienia. Dlatego wydaje się, iż najbardziej stosownym sposobem oddziaływania na osoby w starszym wieku, które stosują przemoc jest praca terapeutyczna, polegająca na kształtowaniu umiejętności zrozumienia dobra i zła, a tym samym zrozumienia własnego sumienia, co może wpłynąć na zmianę ich postaw i zachowań.

Być może kluczem do zrozumienia postępowania sprawcy przemocy jest próba odwrócenia ról, tj. pokazanie osoby stosującej przemoc w roli ofiary. Pokazanie z innego punktu widzenia cierpienia, poczucia krzywdy, być może zrodzi refleksję u osoby stosującej przemoc. Jednak aby terapia okazała się możliwa i w konsekwencji skuteczna, należałoby odizolować sprawcę od środowiska, w którym dotychczas przebywał. Optymalnym rozwiązaniem byłoby usytuowanie placówek przeznaczonych dla osób, które często z racji uzależnienia alkoholowego bądź przeszłości kryminalnej mają problem z odróżnieniem dobra od zła, w otoczeniu sprzyjającym wyciszeniu, kontemplacji. Może w takim miejscu łatwiej by im było wsłuchać się w głos własnego sumienia, nim będzie za późno.

\section{Zakończenie}

Żaden człowiek, nawet sprawca przemocy, nie jest pozbawiony sumienia. Wydaje się, iż z punktu widzenia sumienia sprawcy przemocy, możliwość umieszczenia osób skłonnych do przemocy w ośrodkach oddalonych od ich dotychczasowego środowiska zamieszkania oraz grupy koleżeńskiej wydaje się celowa i sensowna. L. Pertażycki zwraca uwagę, iż zewnętrzne emocje, określane - przez niego - jako „akcje" sprawiają iż jednostki komunikują się ze sobą przy jednoczesnym przekazywaniu podobnych emocji, co prowadzi do zarażania emocjo- 
nalnego ${ }^{34}$. Dlatego istotne jest, by osoby stare, skłonne do stosowania przemocy, były umieszczane $\mathrm{z}$ dala od dotychczasowego środowiska, $\mathrm{w}$ instytucjach przygotowanych do otoczenia ich opieką. Tego rodzaju działania mogłyby zaowocować głębszym poznaniem siebie samego, co być może przyczyniłoby się do wyjścia z nałogu i zaniechania agresji względem innych.

Nie bez znaczenia jest także prowadzenie badań naukowych celem zrozumienia powodów działania osób starszych stosujących przemoc. We wstępie postawiono szereg pytań dotyczących motywów postępowania sprawcy przemocy i roli sumienia w podejmowanych działaniach. Nie ma możliwości udzielenia odpowiedzi na wszystkie z nich, bez rozmowy z osobami stosującymi przemoc, która da możliwość poznania ich opinii na temat sumienia i jego roli w życiu człowieka, a w sposób szczególny wpływu sumienia na podejmowanie aktów przemocowych.

Słowa kluczowe: sumienie, przemoc, człowiek stary

\section{Bibliografia}

Biesaga T., Sumienie, [w:] Powszechna encyklopedia filozoficzna, t. 9, Lublin 2008. Cichocka M., Zjawisko i formy przemocy wobec ludzi starych, [w:] Agresja i przemoc a zdrowie psychiczne, Warszawa-Poznań 2001.

Halicka M., Przemoc wobec starszych kobiet - wywiady z ofiarami „Praca Socjalna" 2012, nr 5.

Halicka M., Halicki J. (red.), Przemoc wobec ludzi starych, Białystok 2010.

Halicka M., Szafranek A., The living space of elderly female victims of intimate partner violence in view of court acts, [w:] J. Maćkowiak, E. Pająk-Ważna (red.), Women in different global contexts, Kraków 2014.

Halicka M., Szafranek A., Zjawisko przemocy w populacji osób starszych, [w:] M. Cybulski, E. Krajewska-Kułak (red.), Opieka nad osobami starszymi. Przewodnik dla zespołu terapeutycznego, Warszawa 2016.

Kosiorek M., Przemoc symboliczna w edukacji, [w:] R. Szczepanik, J. Wawrzyniak (red.), Różne spojrzenia na przemoc, Łódź 2008.

Leszczyna H., Petrażycki, Warszawa 1974.

Mariański J., Kryzys moralny czy transformacja wartości? Studium socjologiczne, Lublin 2001.

Maritain J., Pisma filozoficzne, tłum. J. Fenrychowska, Kraków 1988.

${ }^{34}$ L. Petrażycki, Emocjonalne zarażenia, s. 19-20. 
Motyka K., Wpływ Leona Petrażyckiego na polska teorię $i$ socjologię prawa, wyd. KUL, Lublin 1993.

Petrażycki L., Emocjonalne zarażenia, „Studia Socjologiczne” 2011, nr 2 (201).

Petrażycki L., O nauce, prawie i moralności. Pisma wybrane, Warszawa 1985.

Podsiad A., Więckowski Z. (opr.), Mały słownik terminów i pojęć filozoficznych dla studiujących filozofię chrześcijańska, Warszawa 1983.

Reber A.S., Reber E.S., Stownik psychologii, Warszawa 2008.

Szafranek A., Czynniki sprzyjające przemocy z udziatem osób starszych w domach pomocy społecznej w województwie podlaskim, [w:] P. Błędowski, A. Stogowski, K. Wieczorowska-Tobis (red.), Wyzwania wspótczesnej gerontologii, Poznań 2013.

Szatur-Jaworska B., Błędowski P., Dzięgielewska M., Podstawy gerontologii społecznej, Warszawa 2006.

Św. Tomasz z Akwinu, Traktat o człowieku. Summa teologii, 1, 75-89, tłum. i oprac. S. Swieżawski, Kęty 2000.

Świtka J., Filozoficzne i socjologiczne ujęcie kary, [w:] M. Kuć, I. Niewiadomska (red.), Kara kryminalna. Analiza psychologiczno-prawna, Lublin 2004.

\section{THE PERPETRATOR'S CONSCIENCE - ETHICAL AND SOCIO-LEGAL ASPECTS OF VIOLENCE AMONG ELDERLY}

\section{S u m m a r y}

The presented paper will address the issue of the conscience of an elderly perpetrator of violence, focusing its ethical, social and legal aspects. It is based on the opinions of experts in ethics, legal sociology, and philosophy. The theoretical perspective is supported with references to research on violence, conducted in three social care homes in Podlasie, as well as research conducted as part of international projects, which had the aim of diagnosing and improving intervention measures used in cases of marital violence against elderly women.

Key words: conscience, violence, the elderly

\section{НАСИЛИЕ СРЕДИ ПОЖИЯЫХ ЛЮДЕЙ - ЭТИЧЕСКИЕ И СОЦИАЯЬНО ПРАВОВЫЕ АСПЕКТЫ}

\section{Р е 3 го м}

Представленная статья касается темы совести пожилого человека, совершившего насилия. Особое внимание посвящено этическим и социально-правовым аспектам. Основным источником является мнения этиков, социологов права и философов. Теоретическое понятия совести 
совершившего насилия приклоняется к исследованиям касательно насилия, совершившего в трех домах престарелых в подласком воеводстве, а также исследований проведенных в приделах международных проектов, целью которых был диагноз и улучшение интервенционных действий в случаях насилия относительно старших женщин со стороны мужа.

Ключевые слова: совесть, насилие, старый человек 